\title{
Self-immobilised bacterial consortium culture as ready-to-use seed for crude oil bioremediation under various saline conditions and seawater
}

\author{
W. Kok Kee $\cdot$ H. Hazaimeh $\cdot$ S. A. Mutalib $\cdot$ \\ P. S. Abdullah $\cdot$ S. Surif
}

Received: 1 August 2013/Revised: 11 April 2014/ Accepted: 10 May 2014/Published online: 4 June 2014

(C) Islamic Azad University (IAU) 2014

\begin{abstract}
Biodegradation of crude oil hydrocarbon by microorganisms in seawater is generally slow because of the harsh environmental condition due to high salinity. The aim of this study was to compare sawdust (SD) and oil palm empty fruit bunch wastes as suitable carrier material to immobilise hydrocarbon-degrading bacterial consortium culture to accelerate and improve crude oil degradation in seawater. The consortium culture was found able to tolerate salinity up to $3 \%$, where the degradation of crude oil was not inhibited $(p>0.05)$. In artificial seawater, suspension of bacterial consortium culture was able to degrade $83.3 \pm 3.00 \%$ of crude oil within 8 weeks, which indicated the possibility of using consortium culture in seawater. When tested in seawater, suspension of consortium culture managed to degrade $47.7 \pm 1.53 \%$ of crude oil in 8 weeks. In order to improve the performance of consortium culture, immobilisation of consortium culture onto SD and oil palm empty fruit bunch was successfully undertaken when formation of biofilm layers was observed under scanning electron microscope. Immobilising consortium culture onto oil palm empty fruit bunch and SD was shown to increase crude oil biodegradation to $68.7 \pm 4.04$ and $62.3 \pm 5.51 \%$ in 8 weeks, respectively. This study demonstrated immobilisation of consortium culture onto SD and oil palm empty fruit bunch can be utilised as ready-to-
\end{abstract}

W. Kok Kee $(\bowtie) \cdot$ H. Hazaimeh · S. A. Mutalib · S. Surif Faculty of Science and Technology, Universiti Kebangsaan Malaysia (UKM), 43600 Bangi, Selangor D.E., Malaysia e-mail: anson_gulf@yahoo.co.uk

P. S. Abdullah

Faculty of Health and Life Sciences, INTI International University, Persiaran Perdana BBN, Putra Nilai, 71800 Nilai, N. Sembilan, Malaysia use seeds to improve and accelerate crude oil biodegradation in seawater.

Keywords Bacteria $\cdot$ Biodegradation - Biofilm · Carrier materials $\cdot$ Hydrocarbon $\cdot$ Petroleum wastes

\section{Introduction}

Seawater pollution by crude oil hydrocarbon is a serious international concern for it causes ecological damage to marine shorelines and having an adverse impact on fishery activities and public health (Vila et al. 2010). The main sources of seawater hydrocarbon pollution are crude oil offshore exploration and the use and transportation of crude oil products. Physicochemical methods used to remove hydrocarbon pollution are costly and limited in effectiveness (Eawniczak et al. 2010). Therefore, there is an increase tension to develop environmental-friendly and cost-effective method (Bao et al. 2012). At present, bioremediation using microbial cells has gained popularity because microbes can synthesize a variety of enzymes to degrade an extensive range of hydrocarbons (Mahjoubi et al. 2013), easily regenerated, can be optimised and incorporated into other treatment plants and can be applied in situ or ex situ (ITOPF 2011).

Numerous investigators have studied the use of hydrocarbon-degrading consortia isolated and enriched from polluted marine sediments (Mille et al. 1991) or from hypersaline environments such as salt marshes (Bertrand et al. 1993). In the present study, consortium culture (CC) with metal-resistant characteristic (Sannasi et al. 2009) will be tested under different salinity, artificial seawater and seawater to degrade crude oil hydrocarbon since crude oil contamination sites are frequently co-contaminated by 
heavy metals as well (Mielke et al. 2004). Of the nine isolates identified using Biolog system, Pseudomonas, Flavobacterium (Ko and Lebeault 1999), Serratia (Fellie et al. 2012) and Brevundimonas have been reported to successfully degrade hydrocarbon compounds such as benzene, toluene, naphthalene, decalin and phenol (Tumaikina et al. 2008), and Alcaligenes (Wentzel et al. 2007) was shown to degrade hydrocarbons. Sathishkumar et al. (2008) further reported on Corynebacterium and Pseudomonas, two dominant strains commonly found in soil with the capability of degrading 54 and $67 \%$ of crude oil, respectively. Ławniczak et al. (2010) reported the ability of Stenotrophomonas maltophilia to degrade diesel oil. The remaining two isolates in this study, Gemella palaticanis and Brevibacterium otitdis, have not yet been reported to degrade hydrocarbons. However, Brevibacterium otitdis was known to produce extracellular polysaccharide (EPS) which can function as biosurfactant (Asker and Shawky 2010) that facilitates emulsification and degradation of crude oil hydrocarbon.

Despite large number of enriched microbes possessing hydrocarbon degradative abilities has been isolated from pollution sites, however, most were unable to adapt to field environment, rendering their application useless (Yakimov et al. 2007). One of the ways to increase survival of bacteria in field application is by immobilising these bacterial cells onto suitable carrier. Carrier surfaces can provide protection and nutrition, which improves the activity and survivability of bacterial cells when introduced to harsh environment (Gentili et al. 2006). In this study, immobilisation of $\mathrm{CC}$ onto sawdust (SD) and oil palm empty fruit bunch (OPEFB) as suitable carriers to improve and accelerate crude oil biodegradation in seawater was further investigated for the purpose of practical application as ready-to-use seeds for bioremediation. Selection of OPEFB is based on reported waste generated amounting to 50.0 million tons in Malaysia annually (Rahman et al. 2007) and rich in organic content such as fatty acids, which can support bacterial growth (Mumtaz et al. 2008). SD was selected based on existing reports whereby it has been used successfully for immobilisation of bacterial cells (Podorozhko et al. 2008; Obuekwe and Al-Muttawa 2001). Both OPEFB and SD are suitable potential carriers because they are aplenty locally in Malaysia, cheaply available, biodegradable and non-toxic to both bacterial cells and the environment. Furthermore, both OPEFB and SD offer plenty of rough surfaces with macropores to provide wide area for attachments to bacteria.

The research was conducted entirely in the laboratory of Universiti Kebangsaan Malaysia, Malaysia from June 2009 to April 2012. Seawater was collected from Port Dickson-
Malaysia (latitude N $02^{\circ} 32^{\prime} 31.9^{\prime}$, longitude E $101^{\circ} 47^{\prime} 56.0^{\prime}$ ) in July 2010.

\section{Materials and methods}

\section{Bacterial sources}

The bacterial CC used in this study was previously isolated from industrial waste water (Sannasi et al. 2009) and was shown able to degrade benzene, toluene, xylene and ethylbenzene, monoaromatic compounds commonly found in crude oil (Fellie et al. 2012; Kok-Kee et al. 2013). From the glycerol stock, the CC was re-grown in fresh nutrient broth and incubated at $29 \pm 1{ }^{\circ} \mathrm{C}$ on a rotary shaker at $200 \mathrm{rpm}$. At the end of $24 \mathrm{~h}$, the bacterial CC cells were harvested by centrifugation at $3,000 \mathrm{rpm}$ for $15 \mathrm{~min}$ and the pellet obtained was then rinsed twice using saline $(0.85 \% \mathrm{NaCl})$. The rinsed pellet was then resuspended using fresh saline to obtain a cell density of $4.71 \times 10^{7} \mathrm{CFU} / \mathrm{mL}$ as enumerated using pour plate method (Hamzah et al. 2013) and served as starting inoculums.

\section{Biodegradation of crude oil under different salinity}

The ability of CC to degrade crude oil under different salinity was tested. Minimal salt media (MSM) with salinity of 1, 2, 3, 4 and $5 \%$ was prepared by dissolving $\mathrm{NaCl}$ salt in MSM $\left(1.0 \mathrm{~g}\right.$ of $\mathrm{K}_{2} \mathrm{HPO}_{4}, 1.0$ of $\mathrm{KH}_{2} \mathrm{PO}_{4}, 1.0 \mathrm{~g}$ of $\mathrm{NaCl} ; 1.0 \mathrm{~g}$ of $\mathrm{KNO}_{3} ; 0.2 \mathrm{~g}$ of $\mathrm{MgSO}_{4}$ and $0.02 \mathrm{~g}$ of $\mathrm{CaCl}_{2}$ in $1 \mathrm{~L}$ of deionised distiled water), autoclaved and the $\mathrm{pH}$ adjusted to $7.0 \pm 0.2$. Biodegradation experiments were conducted in Erlenmeyer flask containing MSM $(98.0 \mathrm{~mL})$ with different salinity, inoculated with $1.0 \mathrm{~mL}$ of CC starting inoculums and then added with $1.0 \mathrm{~mL}$ of crude oil. The flask was then incubated on a rotary shaker at $200 \mathrm{rpm}$ and $29.0 \pm 1{ }^{\circ} \mathrm{C}$. Crude oil degradation was measured after 2 weeks. At the end of the incubation period, $1.0 \mathrm{~mL}$ of the culture was analysed for growth of CC using pour plate method (Hamzah et al. 2013) and the rest were extracted using $n$-hexane for analysis of crude oil residues using GC-FID ("Extraction and gas chromatographic (GC-FID) analysis of residual crude oil" section).

Biodegradation in artificial seawater

The potential of bacterial CC to degrade crude oil under seawater condition was first studied using artificial seawater. Artificial seawater (ASW) was prepared according to Austin (1993) by mixing $1 \mathrm{~g} / \mathrm{L} \quad \mathrm{NH}_{4} \mathrm{Cl} ; 1.47 \mathrm{~g} / \mathrm{L}$ $\mathrm{CaCl}_{2} \cdot 2 \mathrm{H}_{2} \mathrm{O} ; 0.026 \mathrm{~g} / \mathrm{L} \quad \mathrm{H}_{3} \mathrm{BO}_{3} ; 0.68 \mathrm{~g} / \mathrm{L} \quad \mathrm{KCl} ; 10 \mathrm{~g} / \mathrm{L}$ $\mathrm{MgCl}_{2} ; 0.196 \mathrm{~g} / \mathrm{L} \quad \mathrm{NaHCO}_{3} ; 4 \mathrm{~g} / \mathrm{L} \quad \mathrm{Na}_{2} \mathrm{SO}_{4} ; 0.5 \mathrm{~g} / \mathrm{L}$ $\mathrm{K}_{2} \mathrm{HPO}_{4}$; and $30 \mathrm{~g} / \mathrm{L} \mathrm{NaCl}$ to give $3 \%$ salinity to the ASW 
and autoclaved at $121^{\circ} \mathrm{C}$ for $15 \mathrm{~min}$. Biodegradation experiments were conducted in Erlenmeyer flask containing $98.0 \mathrm{~mL}$ of ASW, inoculated with $1 \mathrm{~mL}$ of CC starting inoculums and $1 \mathrm{~mL}$ of crude oil hydrocarbon as sole carbon source. The inoculated media were then incubated on a shaker at $200 \mathrm{rpm}$ and $29.0 \pm 1{ }^{\circ} \mathrm{C}$. At every 2 weeks, $1.0 \mathrm{~mL}$ of the culture was analysed for growth using pour plate method and the rest were extracted using $n$-hexane for analysis of crude oil residues using GC-FID ("Extraction and gas chromatographic (GC-FID) analysis of residual crude oil" section).

Sampling and analyses of seawater

Seawater was collected from Port Dickson-Malaysia (latitude $\mathrm{N} 02^{\circ} 32^{\prime} 31.9^{\prime}$, longitude E $101^{\circ} 47^{\prime} 56.0^{\prime}$ ), in July 2010 and kept in sterile glass bottles, transported to the laboratory to be analysed for total petroleum hydrocarbon contents and indigenous microbial population within $24 \mathrm{~h}$.

The total petroleum hydrocarbons (TPH) were measured by extracting $1 \mathrm{~L}$ of seawater with $30 \mathrm{~mL}$ chloroform, and the extract was then evaporated in a vacuum evaporator (EYELA N-1000, Japan) with the water bath temperature set at $50{ }^{\circ} \mathrm{C}$. The TPH residue after evaporation was redissolved in $1 \mathrm{~mL}$ of $n$-hexane and analysed using GC-FID as described in "Extraction and gas chromatographic (GCFID) analysis of residual crude oil" section. The number of indigenous bacteria in the seawater samples was determined using spread plate method on nutrient agar (Oxoid, United Kingdom) and on solid minimal salt media (MSM) supplemented with $1 \%$ of crude oil. The MSM agar was prepared by adding $1.5 \%$ of agar into MSM media and autoclaved at $121{ }^{\circ} \mathrm{C}$ for $15 \mathrm{~min}$ (Sorkhoh et al. 1990). After cooling down to $60{ }^{\circ} \mathrm{C}, 1 \mathrm{~mL}$ (v/v) of crude oil was added into the MSM and poured into petri dishes and left to solidify. In total, $100 \mu \mathrm{L}$ of seawater was spread onto nutrient agar and incubated for $24 \mathrm{~h}$ to assess the population of microbes in seawater. In total, $100 \mu \mathrm{L}$ of seawater was also spread on MSM agar supplemented with crude oil and incubated for 7 days to determine the population of hydrocarbon degrader. Both plates were incubated at $29 \pm 1{ }^{\circ} \mathrm{C}$, and at the end of each incubation period, the bacterial colonies were calculated and expressed as colonyforming units per $\mathrm{mL}(\mathrm{CFU} / \mathrm{mL})$.

Biodegradation of crude oil in seawater

Degradation of crude oil in seawater was carried out in Erlenmeyer flasks that contained $98 \mathrm{~mL}$ of non-sterile seawater added with $1 \mathrm{~mL}$ of filter-sterilised crude oil. In triplicates, flasks were then inoculated with (1) $1.0 \mathrm{~g}$ of OPEFB immobilised with bacterial CC, (2) $1.0 \mathrm{~g}$ of SD immobilised with bacterial $\mathrm{CC}$, (3) $1 \mathrm{~mL}$ of free suspension $\mathrm{CC}\left(10^{7} \mathrm{CFU} / \mathrm{mL}\right)$ and (4) without inoculation of $\mathrm{CC}$ to assess the activity of the indigenous microbial community (positive control). Another three flasks contained autoclaved seawater and filter-sterilised crude oil were prepared to assess abiotic loss of crude oil (negative control). All the flasks were incubated at $29 \pm 1{ }^{\circ} \mathrm{C}$ on an orbital shaker set at $200 \mathrm{rpm}$. Samples were taken on day 14, 28, 42 and 56 and subjected to GC-FID analysis to calculate percentage of crude oil degraded.

For immobilising bacterial CC, two organic carrier, the OPEFB (Malaysian Palm Oil Board Center) and SD from sawmill were used. The OPEFB was shredded to obtain particles with a uniform size approximately $15-20 \mathrm{~cm}$ in length. SD and OPEFB particles collected were then rinsed with boiling water followed by $70 \%$ alcohol and distiled water in order to remove debris and impurity. Both carriers were then autoclaved at $121^{\circ} \mathrm{C}$ for $15 \mathrm{~min}$ and air-dried. Immobilisation of $\mathrm{CC}$ onto carriers was carried out by inoculating $1 \mathrm{~mL}\left(10^{7}\right.$ $\mathrm{CFU} / \mathrm{mL}$ ) of $\mathrm{CC}$ from starting inoculums into $20 \mathrm{~mL}$ vials containing $1 \mathrm{~g}$ of sterilised carrier and incubated at room temperature for 5 days. In order to determine the number of $\mathrm{CC}$ attached to carriers after $24 \mathrm{~h}$ incubation, the carriers were removed and resuspended in $10 \mathrm{~mL}$ of phosphate buffer, sonicated for $2 \mathrm{~min}$ (BRANSON 2210), followed by vortexing for $10 \mathrm{~min}$ to detach CC. In total, $100 \mu \mathrm{L}$ of the detached $\mathrm{CC}$ was then plated onto nutrient agar and incubated at $29 \pm 1{ }^{\circ} \mathrm{C}$ overnight. The numbers of viable bacterial cells on the agar were reported as colony-forming unit $(\mathrm{CFU} / \mathrm{mL})$. The progression of immobilisation of $\mathrm{CC}$ was analysed using $0.01 \mathrm{~g}$ of immobilised $\mathrm{CC}$ and fixed with $4 \%(\mathrm{w} / \mathrm{v})$ glutaraldehyde solution in $0.1 \mathrm{M}$ sodium cocodylate buffer for $24 \mathrm{~h}$ at $4{ }^{\circ} \mathrm{C}$ and washed thrice with $0.1 \mathrm{M}$ sodium cocodylate buffer. Samples were fixed using $1 \%$ osmium tetroxide for $2 \mathrm{~h}$ at $4{ }^{\circ} \mathrm{C}$ and then washed with $0.1 \mathrm{M}$ sodium cocodylate buffer. The samples were then dehydrated using a series of acetone (35-100\%), 10 min each times and dried using the $\mathrm{CO}_{2}$ critical point drying technique for $30 \mathrm{~min}$. The samples were then sputter coated with gold and viewed under scanning electron microscope (SUPRA 55VPGermany) (Díaz et al. 2002).

Extraction and gas chromatographic (GC-FID) analysis of residual crude oil

Residual crude oil was extracted from ASW media, seawater and culture sample (" Biodegradation of 
crude oil under different salinity, Biodegradation in artificial seawater, Sampling and analyses of seawater and Biodegradation of crude oil in seawater" section) according to the International Standard Method ISO 9377-2 (2000) with minor modification that determines long-chain or branched aliphatic, acyclic, aromatic and alkyl-substituted aromatic hydrocarbons. Briefly, samples mixed with $5 \mathrm{~mL} n$-hexane were shaken vigorously and poured into a separation funnel. The contents were rested for $10 \mathrm{~min}$ to allow separation of the organic and aqueous phases. The organic $n$-hexane phase was then collected into a round bottom flask. The extraction process was repeated twice. The extracted crude oil in $n$-hexane was then evaporated on a rotary evaporator (EYELA N-1000, Japan) with the water bath temperature set at $50{ }^{\circ} \mathrm{C}$. The crude oil residue after evaporation was resuspended in $1 \mathrm{~mL} n$-hexane and quantified chromatographically using gas chromatography GC-FID.

One $\mu \mathrm{L}$ of residual crude oil hydrocarbon in $n$ hexane was analysed on a capillary gas chromatograph (Clarus 500 GC, J\&W Scientific, USA) equipped with a $320 \mu \mathrm{m} \times 30 \mathrm{~m}$ silica capillary column (J\&W Scientific, Folsom, CA, USA) and flame ionisation detector (FID). The samples were injected by split injection using helium as carrier gas at a constant flow rate of $1.2 \mathrm{~mL} / \mathrm{min}$, and the oven temperature was programmed as follows: $5 \mathrm{~min}$ at $60{ }^{\circ} \mathrm{C}$ followed by
$5{ }^{\circ} \mathrm{C} / \mathrm{min}$ to $320{ }^{\circ} \mathrm{C}$ and a final bake out at $320{ }^{\circ} \mathrm{C}$ for $10 \mathrm{~min}$. Percentage of crude oil degraded was determined by comparing total area of chromatogram of the test samples with that of the control.

(Total peak area of crude oil sample after incubation/

Total peak area of crude oil of the control) $\times 100$.

\section{Results and discussion}

Effect of salinity on the growth of $\mathrm{CC}$ and crude oil degradation

For practical application of bioremediation in contaminated seawater, bacterial $\mathrm{CC}$ has to overcome osmotic pressure of seawater with higher salinity and maintain their biodegradation activities. Thus, the survivability and degradative ability of $\mathrm{CC}$ were tested in the presence of different salt concentrations. Figure 1 shows that increase in $\mathrm{NaCl}$ concentration caused a decrease in both CC population and percentage of crude oil hydrocarbon degraded. The population of $\mathrm{CC}$ was observed to decrease up to $75.68 \%$ compared with control when the salinity was increased 5 -folds from 1 to $5 \%$. Similarly, the percentages of crude oil hydrocarbon degraded were observed to reduce by 7.59 , $13.00,24.17,56.73$ and $62.85 \%$, respectively, at 1,2 , 3,4 and $5 \%$ salinity when compared to control.
Fig. 1 Bacterial CC population growth and crude oil degradation under different salinity

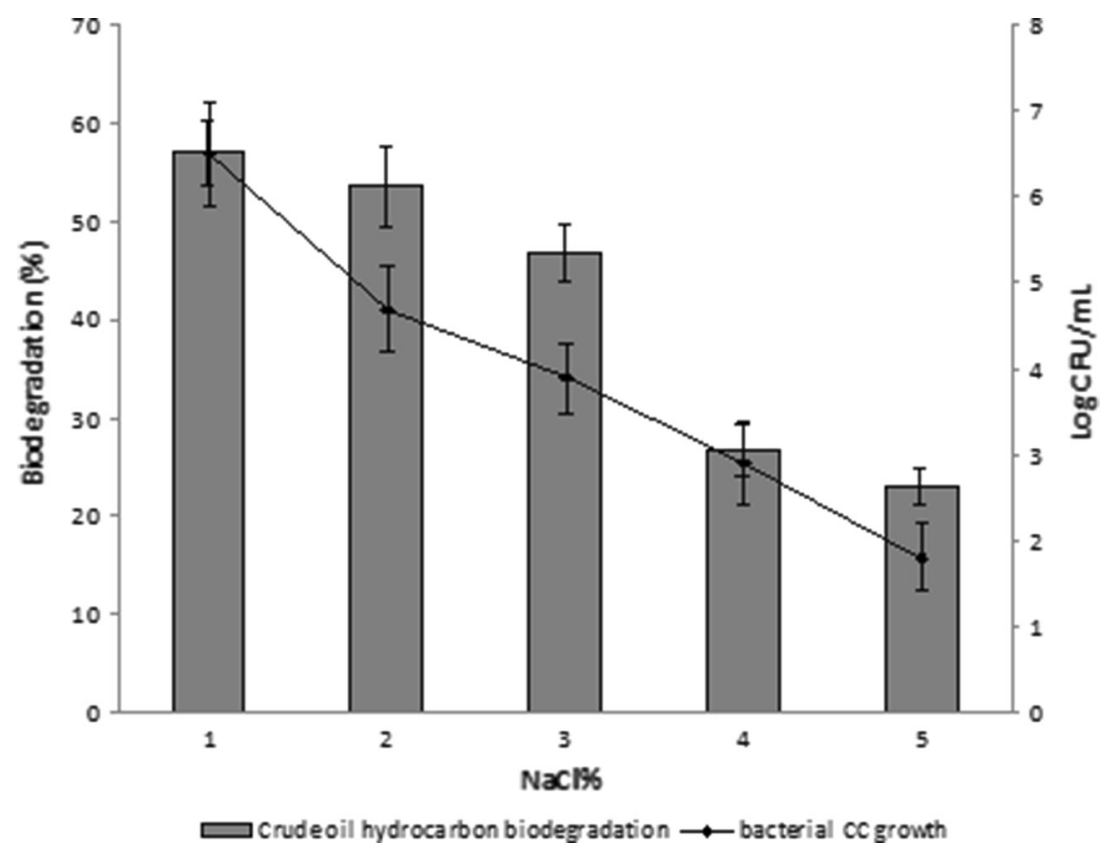


However, the percentage of crude oil degraded at increasing salinity from 1 to $3 \%$ was not significantly different $(p>0.05)$ compared with control. This result suggested degradation of crude oil hydrocarbon by CC was not affected by increasing salinity up to $3 \%$. However, inhibition of crude oil hydrocarbon degradation $>50 \%$ was observed when the salinity exceeded $3 \%$.

Minai-Tehrani et al. (2006) similarly reported a decrease in crude oil degradation from 41 to $12 \%$ when the salinity was increased from 0 to $5 \%$. The study attributed the decrease in crude oil biodegradation to inhibition of microbial growth. Increase in salinity can retard microbial growth by the increasing osmolarity, which causes hyper osmotic shock to microbial cells (Abdulkarim et al. 2009). Salinity at $5 \%$ was reported to inhibit the synthesis of macromolecules (Csonka 1989), which suggests degradative enzymes that play a major role in degrading crude oil hydrocarbons are also inhibited. Furthermore, Ward and Brock (1978) reported that an increase in salinity will decrease oxygen uptake by bacterial cells, resulting decrease in crude oil oxidisation. However, bacterial CC in this study was able to tolerate and maintain its crude oil degradative ability up to $3 \%$ salinity; a salinity similar to seawater (Liu et al. 2009) and thus potentially useful to degrade crude oil in seawater.

\section{Biodegradation of crude oil in artificial seawater by CC}

Figure 2a shows that under artificial seawater (ASW) condition, bacterial $\mathrm{CC}$ was able to degrade up to $83.3 \pm 3.00 \%$ of crude oil within 8 weeks. The CC population was seen to increase by $79 \%$ within the first
2 weeks of incubation (Fig. 2b) that coincided with the rapid degradation of crude oil of $51.0 \pm 4.36 \%$ in the same period. This suggests the crude oil hydrocarbon was rapidly degraded by $\mathrm{CC}$ to obtain carbon source to support growth. The CC population gradually declined after week2 (Fig. 2b) along with the crude oil hydrocarbons degradation, as the carbon source was increasingly depleted.

Consortium culture ability to maintain crude oil hydrocarbon degradative activities despite being exposed to increasing salinity up to $3 \%$ suggested that strains within the $\mathrm{CC}$ were able to activate certain mechanism to preserve the functionality of cells under such harsh condition. Vreeland (1987) reported strains could adapt to high salinity by concentrating compatible solutes to create an osmotic balance between the cytoplasm and the external environment or by altering membrane permeability to control the movement of water and allowing the cell to exist with an ionically dilute cytoplasm. Some bacterial strains can lower its cytoplasmic ionic content compared with the outside medium by activating a $\mathrm{Na}^{+}: \mathrm{H}^{+}$antiporter to maintain a large $\mathrm{Na}^{+}$gradient in the cytoplasm (Vreeland 1987). Within the CC, three of the strains, Pseudomonas fluorescens (Viggor et al. 2013), Brevundimonas and Stenotrophomonas (Mahjoubi et al. 2013) may possess such mechanism since they were reported in other studies to survive in the sea and marine environments. This further strengthens $\mathrm{CC}$ usefulness as bioremediation tool to degrade crude oil hydrocarbon in seawater.

\section{Biodegradation of crude oil in seawater by $\mathrm{CC}$}

The seawater samples collected from station near a petroleum refinery in Port Dickson, Malaysia showed
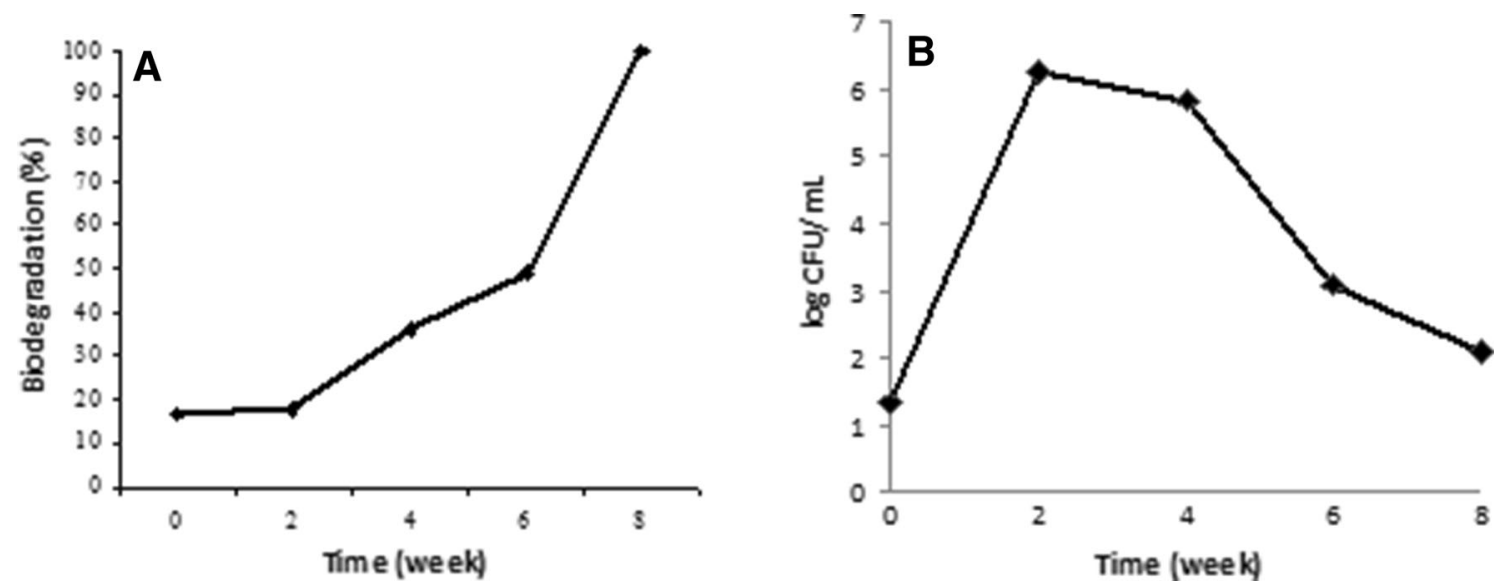

Fig. 2 Crude oil hydrocarbon degradation (a) and bacterial CC growth (b) during 8 weeks in artificial seawater 



Fig. 3 Biofilm formation of CC on (a) SD and (b) OPEFB after 3 days of incubation

the following parameters: temperature $29.6{ }^{\circ} \mathrm{C}$, dissolved oxygen $6.12 \mathrm{mg} / \mathrm{L}$, salinity $3.05 \%, \mathrm{PO}_{4}{ }^{3-}$ $5.24 \mathrm{mg} / \mathrm{L}, \mathrm{NH}_{3} 0.9 \mathrm{mg} / \mathrm{L}$ and $\mathrm{pH}$ 7.63. The concentration of TPH in the sample was $46.21 \mu / \mathrm{L}$, which was safely below the contamination level of $100 \mu / \mathrm{L}$ (Bishop 1983). Approximately $34 \%$ of the total indigenous microbial population found in the seawater samples were crude oil hydrocarbon degraders. The percentage of hydrocarbon degrader found are thrice higher than reported by Atlas (1981) who reported that in pristine environment, microbial hydrocarbon degraders are less than $1 \%$ and in contaminated area exceeding $10 \%$ of the total microbial population. In pristine environment, the microbial hydrocarbon degrader generally degrades hydrocarbon compounds produced naturally by algae and plants (Atlas 1995). Although the seawater sample obtained was found not to be contaminated, the sampling location near to an oil refinery allowed gradual exposure to residual crude oil, which may encourage the indigenous bacteria to start using crude oil hydrocarbon as carbon source.

In order to test whether immobilisation can protect CC from the harsh condition of seawater and hence enhanced degradation of crude oil hydrocarbon, $\mathrm{CC}$ was immobilised onto SD and OPEFB in phosphate buffer. After 3 days of incubation, the surfaces of SD and OPEFB were covered with $\mathrm{CC}$ as observed under scanning electron microscope (Fig. 3). After sonication and washing with saline solution, the number of viable CC dislodged from SD and OPEFB was 60.9 and $64.0 \%$ of the starting inoculums $\left(10^{7} \mathrm{CFU} /\right.$ $\mathrm{mL}$ ), respectively. The number of viable CC immobilised was relatively high and suggested promising performance



Fig. 4 Percentage of crude oil hydrocarbon biodegradations in fresh water using indigenous microbial cells, free $\mathrm{CC}$ and bacterial $\mathrm{CC}$ immobilised onto OPEFB and SD

to degrade crude oil. In comparison, Zhen-Yu et al. (2012) who showed immobilisation of $10^{4} \mathrm{CFU}$ of bacterial cells onto sodium alginate-diatomite reported a $46.3 \%$ of crude oil degradation. Whereas, both SD and OPEFB ability to retain $2.86 \times 10^{7}$ and $3.01 \times 10^{7} \mathrm{CFU}$, respectively, indicated stable survivability and good potential as readyto-use seed in crude oil hydrocarbon degradation application.

Figure 4 shows the highest biodegradation of crude oil was obtained when using bacterial $\mathrm{CC}$ immobilised onto SD and OPEFB as carrier compared with free 




\section{B}
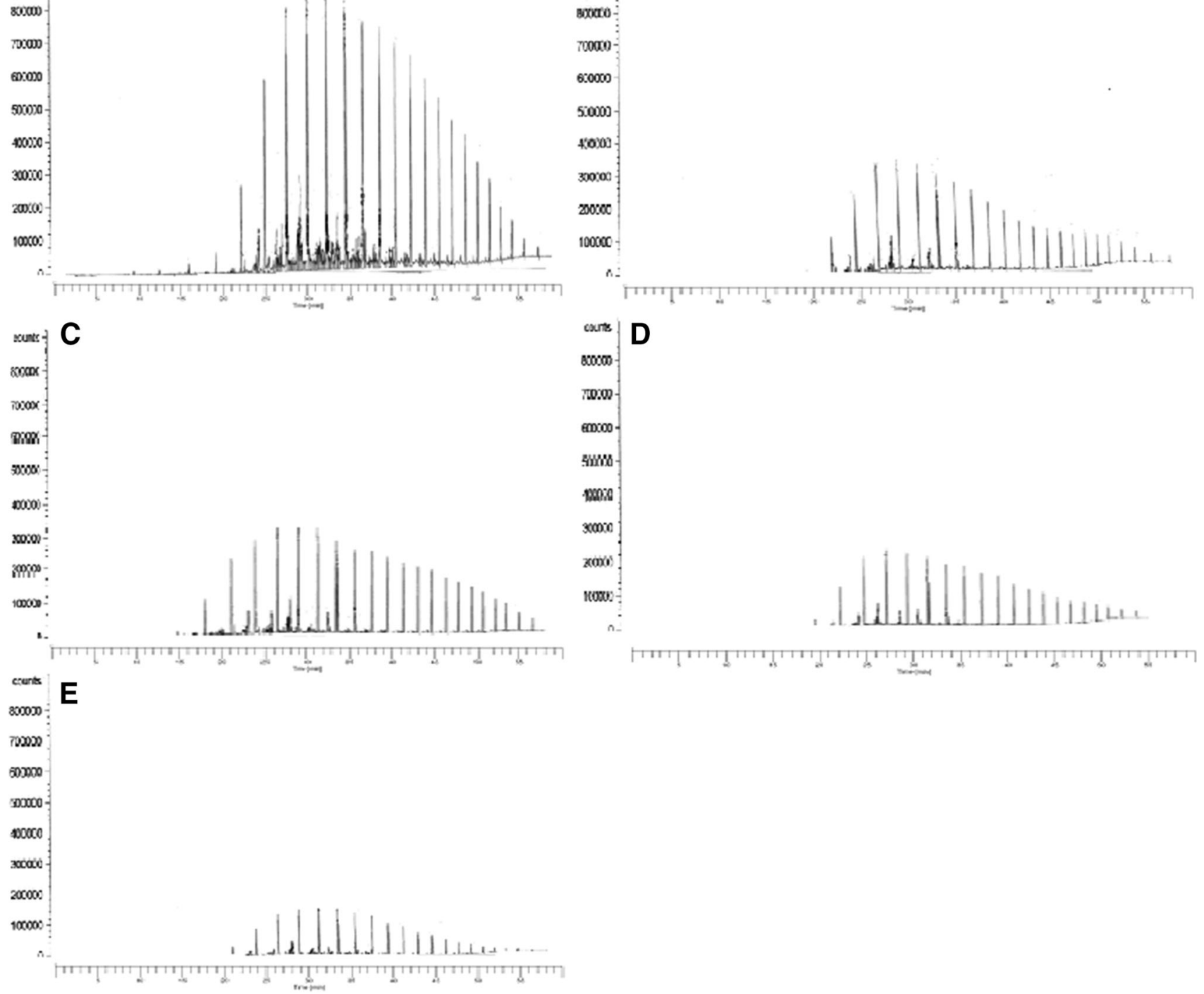

Fig. 5 Gas chromatogram of crude oil at (a) day-0 and after week-8 of incubation using (b) indigenous microbial cells, (c) free CC, (d) immobilised CC onto SD, (e) immobilised CC onto OPEFB

suspension CC. Compared with positive control, inoculation of seawater using free suspension $\mathrm{CC}$ increased degradation from $41.7 \pm 2.52$ to $47.7 \pm 1.53 \%$. Immobilising CC onto SD and OPEFB further enhanced the degradation by 33.7 and $39.3 \%$, respectively, compared with control.

Figure 5 further shows in detail that all the initial peaks detected at day- 0 were significantly reduced after week- 8 using the various treatment. This observation further supported the ability of $\mathrm{CC}$ and the process of immobilising $\mathrm{CC}$ on SD and OPEFB can further enhance degradation. After week-8, all treatments showed rather similar gas chromatogram whereby it suggests that $\mathrm{CC}$ degraded the various light and heavy chains hydrocarbon fractions simultaneously and not selectively, the light chain hydrocarbon first before utilising the heavy chains after the 
former is depleted. This is interesting because microorganisms are widely known to attack short chain hydrocarbons first (Etoumi 2007; Lliròs et al. 2008) as hydrocarbons with lower number of carbon atoms are less hydrophobic and easily available to degradation. One possible explanation is that members within $\mathrm{CC}$ can actively secret biosurfactant to increase the solubility and thus the bioavailability of heavy chain hydrocarbon fractions (C29-C43) within the crude oil for degradation. This is an advantage because heavy chain hydrocarbons are usually rendered non-biodegradable due to their low bioavailability for attachment onto bacterial surfaces with membrane-bound enzymes (Harayama et al. 1999; KokKee et al. 2013).

The ability of free suspension CC to increase crude oil degradation also suggested that $\mathrm{CC}$ was able to survive and compete with the indigenous microbes in the seawater. Immobilising bacterial CC on OPEFB and $\mathrm{SD}$ increased the stability of bacterial $\mathrm{CC}$, and thus, enhanced crude oil degradative activities. The surfaces of SD and OPEFB covered with "pores" and "crevices" encouraged the colonisation of $\mathrm{CC}$, which later developed into an extensive network of biofilm (Fig. 3). In our previous report, we demonstrated the role of exopolysaccharide (EPS) secretion by CC accelerating the biofilm formation on OPEFB and SD (Hazaimeh et al. 2014). Obuekwe and Al-Muttawa (2001) reported lower secretion of EPS by Arthrobacter sp. $(56 \%)$ and another bacillus-like species (43\%) when immobilised on sand. Although at present, we do not know the exact role of the carriers' organic content in relation to biofilm formation; however, circumstantial evidence above suggests the higher organic content in OPEFB and SD, compared with sand, enhanced the secretion of EPS and subsequently influencing the development of biofilm. This interesting aspect of how the organic content of the chosen carriers might influence the outcome of biofilm formation by bacterial cells worth further investigation. Thus, the development of biofilm is an important key strategy by $\mathrm{CC}$ to ensure survivability in hostile marine environment, as in seawater with high salinity. The thick layer of exopolysaccharide surrounding the biofilm prevented desiccation and gives protection against the variation in humidity and against bacteriophage activity (Sutherland 2001), which lends a high survivability percentage of CC after inoculated into seawater. The immobilised CC can be contained into perforated cassette, tubes or similar apparatus and tied to boomers during the initial oil spill clean up operations. This will prevent the immobilised CC from being washed away, and at the same time, degrading the oil spill contained by the boomers. These results suggested $\mathrm{CC}$ immobilised onto SD and OPEFB can be utilised as ready-to-use seeds for in situ application to improve and accelerate crude oil biodegradation in seawater with high salinity.

\section{Conclusion}

Bacterial CC isolated from industrial wastewater was shown first to degrade crude oil under different salinity; then, in artificial seawater and finally in seawater. Immobilising bacterial CC cells onto SD and palm oil empty bunch fruit increased the survivability of $\mathrm{CC}$ through formation of biofilm, leading to enhance biodegradation of crude oil. This study demonstrated immobilisation of $\mathrm{CC}$ onto easily available and cheap material such as SD and OPEFB can be utilised as ready-to-use seeds to improve and accelerate crude oil biodegradation in seawater.

Acknowledgments The work described in this paper was supported by Exxon-Mobil STGL-008-2006 and the Malaysian Ministry of Science, Technology and Innovation (MOSTI), Escience Fund 06-0102-SF0469.

\section{References}

Abdulkarim SM, Fatimah AB, Anderson JG (2009) Effect of salt concentrations on the growth of heat-stressed and unstressed Escherichia coli. J Food Agric Environ 7:51-54

Asker MMS, Shawky BT (2010) Structural characterization and antioxidant activity of an extracellular polysaccharide isolated from Brevibacterium otitidis BTS 44. Food Chem 123:315-320

Atlas RM (1981) Microbial degradation of petroleum hydrocarbons: an environmental perspective. Microb Rev 45:180-209

Atlas RM (1995) Petroleum biodegradation and oil spill bioremediation. Mar Pollut Bull 31:178-182

Austin B (1993) Microbiological methods: marine microbiology. Cambridge University Press, Cambridge, p 24

Bao M, Wang L, Sun P, Cao L, Zou J, Li Y (2012) Biodegradation of crude oil using an efficient microbial consortium in a simulated marine environment. Mar Pollut Bull 64:1177-1185

Bertrand JC, Bianchi M, Mallah MA, Acquaviva M, Mille G (1993) Hydrocarbon biodegradation and hydrocarbon clastic bacterial communities composition grown in seawater as a function of sodium chloride concentration. J Exp Mar Biol 168:125-138 
Bishop PL (1983) Marine pollution and its control. McGraw-Hill Book Company, New York

Csonka NL (1989) Physiological and genetic responses of bacteria to osmotic stress. Microb Rev 53:121-147

Díaz MP, Boyd KG, Grigson SJW, Burgess JG (2002) Biodegradation of crude oil across a wide range of salinities by an extremely halotolerant bacterial consortium MPD-M, immobilized onto polypropylene fibers. Biotechnol Bioeng 79:145-153

Etoumi A (2007) Microbial treatment of waxy crude oils for mitigation of wax precipitation. J Petrol Sci Eng 55:111-121

Fellie EA, Sannasi P, Wong KK, Salmijah S, Kader J (2012) Tolerance and biodegradation of benzene, toluene, ethylbenzene and xylene (BTEX) by a metal acclimatized bacterial consortium culture. Res J Biotechnol 7:52-58

Gentili AR, Cubitto MA, Ferrero M, Rodriguez MS (2006) Bioremediation of crude oil polluted seawater by a hydrocarbon degrading bacterial strain immobilised on chitin and chitosan flakes. Int Biodeter Biodegrad 57:222-228

Hamzah A, Chia-Wei P, Nur Faizah AB, Kok-Kee W (2013) Biodegradation of crude oil by constructed bacterial consortia and the constituent single bacteria isolated from Malaysia. Bioremediat J 17:1-10

Harayama S, Kishira H, Kasai Y, Shutsubo K (1999) Petroleum biodegradation in marine environment. J Mol Microbiol Biotechnol 1(1):63-70

Hazaimeh M, Sahilah AM, Palsan SA, Wong KK, Salmijah S (2014) Enhanced crude oil hydrocarbon degradation by self-immobilized bacterial consortium culture on sawdust and oil palm empty fruit bunch. Ann Microbiol. doi:10.1007/s13213-014-0821-3

International Standard ISO 9377-2 (2000) Water quality-determination of hydrocarbon oil index. Part 2: method using solvent extraction and gas chromatography. http://www.norden.org/en/ publications/publikationer/2003-516/at_download/ publicationfile/. Accessed 16 Dec 2013

International Tanker Owners Pollution Federation Limited (ITOPF) (2011) Use of dispersants to treat oil spills. http://www.itopf. com/spill-response/clean-up-and-response/. Accessed 16 Oct 2012

Ko SH, Lebeault JM (1999) Effect of a mixed culture on cooxidation during the degradation of saturated hydrocarbon mixture. J Appl Microbiol 87:72-79

Kok-Kee W, Brid Q, Salmijah S (2013) Degradation of crude oil in the presence of lead $(\mathrm{Pb})$ and cadmium $(\mathrm{Cd})$ by a metal-adapted consortium culture. Adv Environ Biol 7:577-585

Ławniczak L, Kaczorek E, Olszanowski A (2010) The influence of cell immobilization by biofilm forming on the biodegradation capabilities of bacterial consortia. World J Microbiol Biotechnol. doi:10.1007/s11274-010-0566-5

Liu CW, Chang WN, Liu HS (2009) Bioremediation of $n$-alkanes and the formation of biofloccules by Rhodococcus erythropolis NTU-1 under various saline conditions and seawater. Biochem Eng J 45:69-75

Lliròs M, Gaju N, de Oyteza TG, Grimalt JO, Esteve I, MartinezAlonso M (2008) Microcosms experiments of oil degradation by microbial mats. II. The changes in microbial species. Sci Total Environ 393:39-49

Mahjoubi M, Jaouani A, Guesmi A, Ben Amor S, Jouini A, Cherif H, Najjari A, Boudabous A, Koubaa N, Cherif A (2013) Hydrocarbonoclastic bacteria isolated from petroleum contaminated sites in Tunisia: isolation, identification and characterization of the biotechnological potential. New Biotechnol 30(6):723-733

Mielke HW, Wang G, Gonzales CR, Powell ET, Le B, Quach VN (2004) PAHs and metals in the soils of inner-city and suburban New Orleans, Louisiana, USA. Environ Toxicol Pharmacol $18: 243-247$

Mille G, Almallah M, Bianchi M, Van Wambeke F, Bertran JC (1991) Effect of salinity on petroleum biodegradation. Fresenius J Anal Chem 339:788-791

Minai-Tehrani D, Herfatmanesh A, Azari-Dehkordi F, Minooi S (2006) Effect of salinity on biodegradation of aliphatic fractions of crude oil in soil. Pak J Biol Sci 9:1531-1535

Mumtaz T, Abd-aziz S, Abdul Rahman NA, Phang LY, Shirai Y, Hassan MA (2008) Pilot-scale of recovery of low molecular weight organic acids from anaerobically treated palm oil mill effluent (POME) with energy integrated system. Afr J Biotechnol 21:3900-3905

Obuekwe CO, Al-Muttawa EM (2001) Self-immobilized bacterial cultures with potential for application as ready-to-use seeds for petroleum bioremediation. Biotechnol Lett 23:1025-1032

Podorozhko EA, Lozinsky VI, Ivshina IB, Kuyukina MS, Krivorutchko AB, Philp JC, Cunningham CJ (2008) Hydrophobised sawdust as a carrier for immobilisation of the hydrocarbonoxidizing bacterium Rhodococcus ruber. Bioresour Technol 99:2001-2008

Rahman SHA, Choudhury JP, Ahmad AL, Kamaruddin AH (2007) Optimization studies on acid hydrolysis of oil palm empty fruit bunch fiber for production of xylose. Bioresour Technol 98:554-559

Sannasi P, Kader J, Othman O, Salmijah S (2009) Physical growth and biomass characterization of bacterial cells exposed to $\mathrm{Cd}(\mathrm{II})$, $\mathrm{Cr}(\mathrm{VI}), \mathrm{Ni}(\mathrm{II})$ and $\mathrm{Pb}(\mathrm{II})$. J Environ Res Dev 4:8-18

Sathishkumar M, Binupriya AR, Baik S, Yun S (2008) Biodegradation of crude oil by individual bacterial strains and a mixed bacterial consortium isolated from hydrocarbon contaminated areas. Clean 36:92-96

Sorkhoh NA, Ghannoum MA, Ibrahim AS, Stretton RJ, Radwan SS (1990) Crude oil and hydrocarbon-degrading strains of Rhodococcus rhodochrous isolated from soil and marine environments in Kuwait. Environ Pollut 65:1-17

Sutherland IW (2001) Biofilm exopolysaccharides: a strong and sticky framework. Microbiology 147:3-9

Tumaikina I, Turkovskaia OV, Ignatov VV (2008) Degradation of hydrocarbons and their derivatives by a microbial association based on Canadian pondweed. Prikl Biokhim Mikrobiol 44:422-429

Viggor S, Juhanson J, Joessar M, Mitt M, Truu J, Vedler E, Heinaru A (2013) Dynamic changes in the structure of microbial communities in Baltic Sea coastal seawater microcosms modified by crude oil, shale oil or diesel fuel. Microbiol Res 168(7):415-427

Vila J, Nieto JM, Mertens J, Springael D, Grifoll M (2010) Microbial community structure of a heavy fuel oil-degrading marine consortium: linking microbial dynamics with polycyclic aromatic hydrocarbon utilization. FEMS Microbiol Ecol 73:349-362

Vreeland RH (1987) Mechanisms of halotolerance in microorganisms. Crit Rev Microbiol 14:311-356

Ward DM, Brock TA (1978) Hydrocarbon biodegradation in hypersaline environments. Appl Environ Microbiol 35:353-359 
Wentzel A, Ellingsen TE, Kotlar HK, Zotchev SB, Throne-Holst M (2007) Bacterial metabolism of long-chain $n$-alkanes. Appl Microbiol Biotechnol 76:1209-1221

Yakimov MM, Timmis KN, Golyshin PN (2007) Obligate oil degrading bacteria. Curr Opin Biotechnol 18:257-266
Zhen-Yu W, Ying X, Hao-Yun W, Jian Z, Dong-Mei G, Feng-Min L, Xing B (2012) Biodegradation of crude oil in contaminated soils by free and immobilized microorganisms. Pedosphere $22: 717-725$ 